\title{
MAPPING LAND COVER CHANGE IN SPATIAL PATTERNS OF SEMI-ARID REGION ACROSS WEST KORDOFAN, SUDAN USING LANDSAT DATA
}

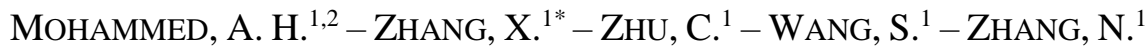 \\ ${ }^{1}$ Beijing Key Laboratory of Precision Forestry, College of Forestry, Beijing Forestry \\ University, Beijing 100083, China \\ ${ }^{2}$ Faculty of Forestry Sciences, University of Zalingei \\ Central Darfur State, Zalingei, P. O. Box 06, Sudan \\ *Corresponding author \\ e-mail: zhangxl@bjfu.edu.cn; phone/fax: +86-10-6233-6227; address: No. 35 Qinghua East \\ Road, Haidian District, Beijing 100083, China \\ (Received 14 ${ }^{\text {th }}$ Aug 2018; accepted $1^{\text {st }}$ Nov 2018)
}

\begin{abstract}
Land cover change information is fundamental to support environmental change studies, land management, and many other societal benefits. Here, we assess and quantify the spatial and temporal land cover changes in West Kordofan, Sudan. With $(30 \mathrm{~m})$ imagery from Landsat ETM+ for the entire West Kordofan, land cover maps were created to explore the changes in spatially explicit way. The results suggest that land cover changes observed in West Kordofan for 2000 to 2015 reflect emerging environmental risks such as rapidly sand encouragement and land degradation. Sand plain, burnt area and forest increased by approximately $7733.28 \mathrm{~km}^{2}, 810.27 \mathrm{~km}^{2}$ and $258.99 \mathrm{~km}^{2}$, respectively. The largest relative land cover change over the entire study period was the increase of sand plain. Expansion of sand plain resulted mainly from desert encouragement towards south direction. Accurate information on the patterns of land cover in West Kordofan may contribute to the future establishment of better land use and land cover polices for an effective land management. In addition, land cover information may also help decision-makers to understand and respond appropriately to emerging environmental risks for the inhabited people.
\end{abstract}

Keywords: land cover, remote sensing, image classification, change detection, GIS, West Kordofan

\section{Introduction}

Land cover represents an important factor in environmental change analysis, from physical environmental studies to spatial planning approaches (Huang et al., 2017; Lambin and Ehrlich, 1997; Padonou et al., 2017). It is a dynamic variable that reflects the interaction between human activities and environmental changes, and therefore, it is necessary to be mapped (Brown et al., 2018; Higginbottom et al., 2018). Mapping land cover changes in ecologically sensitive environment (semi-arid zone) is essential to locate, assess, and rank areas at risk (Higginbottom et al., 2018; Lambin et al., 2003). Furthermore, analyzing vulnerability, and improving land use planning to meet sustainable goals are required for an effective land management (Akinyemi and Mashame, 2018; Dimobe et al., 2015).

West Kordofan has been experienced some considerable amount of pressure during last two decades due to desertification and land degradation (Ayoub, 1999). Desert encroachment and intensive human activities induced dramatic changes in land cover across the region (Dawelbait and Morari, 2012). During last 17 years, desert south border has moved into south part of the region with an average of 90-100 km (Ayoub, 1998). Consequently, this rate of desert encroachment leads to gradual and prolonged 
vegetation loss over extensive areas in the region. According to (Ayoub, 1998) desert is continued moving to south at rate of 5-6 km per year. As the result, desertification across the region has transformed a vast area into arid zone and therefore created large area that has no sufficient quality life-supporting natural resources base and climatic conditions. Importantly, this permanent loss of vegetation cover leads to declining of Acacia Senegal natural stands, which is an important indigenous tree species in the region (Yagoub et al., 2017), but up to date detailed land cover map for West Kordofan and their spatial coverage still unknown. Therefore, mapping West Kordofan land cover is an urgent to public and scientific society, ranging from societal needs to sustainable land management.

Remote sensing has long been identified as an effective tool for large-scale land cover monitoring (Foody, 2001; Hansen and Loveland, 2012; Rogan et al., 2003; Schulz et al., 2010), and they are useful for land cover mapping (Petropoulos et al., 2012). It was, therefore, used efficiently in a number of land cover classification, mapping, and change detection studies using different satellite images with various resolutions (Badjana et al., 2017; Baker et al., 2006; Friedl et al., 2002; Leiterer et al., 2018; Salih et al., 2017). This success of remote sensing satellites is attributed to a range of advantages including wide range of geographical coverage and multi-spectral bands in each image (Liu et al., 2018). Moreover, premise of using remote sensing data is basically based on availability and accessibility of freely Landsat archived data, which offers a unique opportunity for mapping land cover of almost any region on Earth and assess both natural and human disturbances (Costa et al., 2018; Ehrlich et al., 1997). Therefore, combination of Landsat Enhanced Thematic Mapper (ETM+) images and geographic information system (GIS) techniques is a practical option to classify and map the land cover in West Kordofan area.

This study aims to quantify and describe the spatial and temporal patterns of land cover change in West Kordofan between 2000 and 2015. Maps that document accurately the patterns of land cover change in West Kordofan can form the basis for future land cover and land use planning and protection. This spatially explicit information on land cover change may also help to understand and respond rapidly and effectively to emerging environmental risks such as sand encouragement and desertification.

\section{Materials and methods}

\section{Study area}

West Kordofan is located in semi-arid zone of Sudan, and its administrative boundary includes eight Landsat ETM+ images with the path/row: 174/53; 175/51; $175 / 52 ; 175 / 53 ; 176 / 50 ; 176 / 51 ; 176 / 52 ; 176 / 53$ in World Reference System -2 (WRS2) (Fig 1). The surface area covered is approximately $114389.6841 \mathrm{~km}^{2}$, extending between north latitude $9^{\circ}-14^{\circ}$ and east longitude $27^{\circ}-29^{\circ}$. West Kordofan is representative of semi-arid climate in terms of both landscape structure and land surface cover. The terrain varies highly from sea level to approximately $986 \mathrm{~m}$, whereas the vegetation of the area also varies with altitude. The climate of the area is typical semiarid, characterized by hot summers, and cool winters, with a long dry period starting in November and lasting until July (beginning of rainy season) (Elagib and Elhag, 2011). The north part of West Kordofan is covered mainly by sand and some farms land. South part is covered mainly by woodland as well as forest of different tree species. The study 
area experienced severe drought during 1983-1984, 1990-1991 and 2004-2005 (Elagib, 2015).

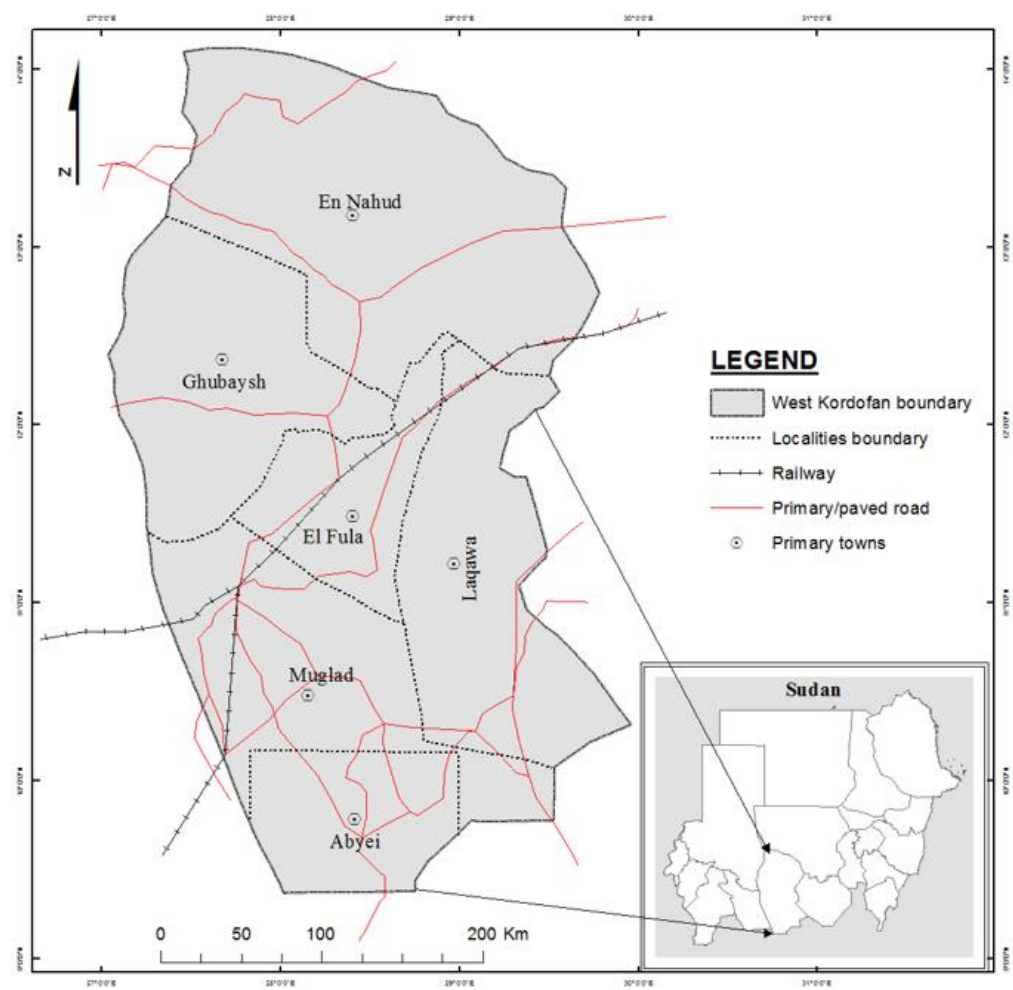

Figure 1. Location of West Kordofan in Sudan

\section{Data acquisition}

The primary data used in this study were acquired from Landsat Enhanced Thematic Mapper Plus (ETM+) for the years 2000 and 2015. A total of sixteen Landsat ETM+ images located by satellite path/row 176/50, 176/51, 176/52, 176/53, 175/51, 175/52, $175 / 53$ and174/53 were used. These images were downloaded free of cost from archive database at http://glovis.usgs.gov/. In addition, a $30 \mathrm{~m}$ spatial resolution Digital Elevation Model (DEM) derived from the Shuttle Rader Topography Mission (SRTM) which provided an important non-spectral input for classification by characterizing elevation and slope related to different land cover categories (Table 1). Besides, training reference points on spatial location, land cover categories and topographic characteristics were collected form detailed field survey, which was carried out during dry season (January to March 2015). A total of 1173 points were collected using Global Positioning System (GPS) receiver (Fig. 2).

\section{Data pre-processing}

For land cover mapping, various requirements of pre-processing, for example, geometric correction, radiometric and atmospheric corrections are the most important to avoid spurious results produced from these issues (Lu et al., 2004). In this study, all downloaded images were level-1 products which were rectified, geometrically and topographically corrected. All images were converted from digital numbers (DNs) to 
top of atmosphere reflectance using the method suggested by Chander et al. (2009): Image pre-processing prior to classification is immensely needed and has a primary unique objective of establishing more direct affiliation between acquired data and biophysical features as well as for producing spatially corrected land cover map (Foody, 2010). Dark object subtraction was used to correct atmospheric effects. Layers stacking was performed to combine the spectral bands of Landsat ETM+ images. Mosaic was applied for the paths and rows: 176/50, 176/51, 176/52, 176/53, 175/51, 175/52, 175/53 and174/53. All the images pre-processing steps were carried out using software ENVI 5.1 and ArcGIS 10.2.

Table 1. Characteristics of Landsat ETM+ images and SRTM data used in this study

\begin{tabular}{c|c|c|c|c|c|c}
\hline Datasets & Date & $\begin{array}{c}\text { Spatial } \\
\text { resolution } \\
\text { scale, } \mathbf{m}\end{array}$ & $\begin{array}{c}\text { Spectral } \\
\text { bands }\end{array}$ & $\begin{array}{c}\text { Swath, } \\
\mathbf{k m}\end{array}$ & Source & Format \\
\hline $\begin{array}{c}\text { Landsat 7 } \\
\text { ETM+L1T }\end{array}$ & Nov. 2015 & 30 & 8 bands & 183 & http://glovis.usgs.gov/ & GeoTiff \\
\hline SRTM & Nov. 2015 & 30 & 1 band & Global & https://earthexplorer.usgs.gov/ & GeoTiff \\
\hline
\end{tabular}



Figure 2. Location of training reference points collected during the field survey that carried out from January to March 2015 in West Kordofan

\section{Selection of training pixels and classification}

Land cover and, in particular, vegetation cover is dynamic, complex and change due to both the climate and human activities (Lambin et al., 2003). To map the land cover, 
and to enhance its classification, Normalized Different Vegetation Index (NDVI) was calculated to assess the extent and status of vegetation cover across the study area. The NDVI separates vegetated and non-vegetated areas and is a useful technique for normalizing the vegetation variable conditions (Sinha et al., 2016). The NDVI calculation is based on the ratio between red and near infrared regions of electromagnetic spectrum using Equation 1 (Chamaille-Jammes et al., 2006).

$$
N D V I=\frac{R E D-N I R}{R E D+N I R}
$$

The given values range between -1 and +1 , where values less than 0 represent areas that contain no vegetation and values greater than 0 represent pixels or areas in which vegetation is increasing (Madonsela et al., 2018).

Prior to the classification, the NDVI was produced for the images of 2000 and 2015 to facilitated to separate the spectral values and selection of training pixels process. The maximum likelihood classifier was the selected method for the process of supervised classification. It is the sort of image classification that is mainly controlled by the analyst as the analyst chooses the pixels that representative of the desired classes.

The classification was divided into six land cover categories included: natural water bodies, farm on sand, sand plain, forest, woodland and burnt area. The features sets used to generate the land cover maps were based on the spectral patterns of Landsat ETM+ images, NDVI and field survey observations.

To improve the classification accuracy and reduction of misclassified pixels, postclassification refinement was therefore applied for simplicity and effectiveness of the method (Yousefi et al., 2015). Importantly, using medium spatial resolution data such as that of Landsat ETM+ mixed pixels are a common issue (Lu and Weng, 2007); especially for the complex area characterized by complex features. The issue of mixed pixels was addressed by visual interpretation. To enhance the classification accuracy and therefore the quality of produced land cover maps, visual interpretation is very important. Thus, visual analysis, training reference points, and local knowledge, considerably improved the result derived by using maximum likelihood supervised classification technique.

\section{Accuracy assessment}

Assessment of classification accuracy of final produced land cover maps were carried out to determine the quality of information derived from the Landsat ETM+ images. For the accuracy two different methods associated with two independent validation datasets. The classified image of 2015 was assessed for accuracy by using 423 reference points that collected through the field survey. We then compared the observed (reference points) label of every sample to the map label and the results summarized in confusion matrix. In the second method, the accuracy assessment was carried out using stratified random sampling procedure to generate the reference points. Care was taken to create sample points for 2000 classification map.

As the extent of each land cover category different, the size of the sample points varied among different classes. A total of 138 reference points were collected and checked against Google Earth Pro image. Then a confusion matrices were calculated to assess the accuracy of the final land cover maps. A confusion matrix is a simple crosstabulation of each mapped class vs. the reference point. Overall accuracy, user's and 
producer's accuracies were then calculated for each land cover category as shown in Table 2. Moreover, Kappa statistic was also derived for estimating degree of classification accuracy as it not only account for diagonal elements but for whole confusion matrix elements.

\section{Land cover change detection}

Change detection is a very common and powerful application of satellite based remote sensing. Change detection entails findings the type, rate and location of land cover changes that are taking place (Kashaigili et al., 2006).

In this study, post-classification comparison was used to quantify the extent of land cover changes over the 15 years period (2000 to 2015). The merit of post-classification comparison is that it bypasses the difficulties associated with the analysis of the images that are obtained at different times of the year, or by different sensors and results in high change detection accuracy.

Table 2. Classification accuracy assessment of 2015 Landsat ETM+ image using error matrix

\section{a) Year 2000}

\begin{tabular}{c|c|c|c|c|c|c|c|c}
\hline $\begin{array}{c}\text { Number of } \\
\text { pixels }\end{array}$ & \multicolumn{7}{c}{ Training reference points } & TA \\
\hline Land cover & NWP & FS & SP & F & WL & BA & Total & UA (\%) \\
\hline NWP & $\mathbf{1 1}$ & 0 & 1 & 0 & 2 & 0 & 14 & 78.6 \\
\hline FS & 0 & $\mathbf{2 3}$ & 3 & 0 & 0 & 1 & 27 & 85.2 \\
\hline SP & 1 & 2 & $\mathbf{1 4}$ & 1 & 1 & 0 & 19 & 73.7 \\
\hline F & 0 & 2 & 1 & $\mathbf{2 0}$ & 1 & 1 & 25 & 80.0 \\
\hline WL & 0 & 1 & 2 & 3 & $\mathbf{3 4}$ & 1 & 41 & 82.9 \\
\hline BA & 0 & 1 & 0 & 1 & 1 & $\mathbf{9}$ & 12 & 75.0 \\
\hline Total & 12 & 29 & 21 & 25 & 39 & 12 & $\mathbf{1 3 8}$ & \\
\hline PA (\%) & 91.6 & 79.3 & 66.6 & 80.0 & 87.1 & 75.5 & & \\
\hline
\end{tabular}

b) Year 2015

\begin{tabular}{c|c|c|c|c|c|c|c|c}
\hline $\begin{array}{c}\text { Number of } \\
\text { pixels }\end{array}$ & \multicolumn{7}{c}{ Training reference points } \\
\hline Land cover & NWP & FS & SP & F & WL & BA & Total & UA (\%) \\
\hline NWP & $\mathbf{2 9}$ & 1 & 0 & 0 & 4 & 0 & 34 & 85.2 \\
\hline FS & 0 & $\mathbf{1 0 6}$ & 5 & 0 & 0 & 0 & 111 & 95.4 \\
\hline SP & 0 & 6 & $\mathbf{6 0}$ & 0 & 1 & 0 & 67 & 89.5 \\
\hline F & 0 & 0 & 0 & $\mathbf{4 0}$ & 2 & 2 & 44 & 90.9 \\
\hline WL & 0 & 1 & 0 & 5 & $\mathbf{1 1 7}$ & 3 & 126 & 92.8 \\
\hline BA & 1 & 0 & 0 & 2 & 2 & $\mathbf{3 6}$ & 41 & 87.8 \\
\hline Total & 39 & 114 & 65 & 47 & 126 & 41 & $\mathbf{4 2 3}$ & \\
\hline PA (\%) & 74.3 & 92.9 & 92.3 & 85.1 & 92.8 & 87.8 & & \\
\hline & \multicolumn{7}{l}{ Overall accuracy =91.9\%, Kappa coefficient = 0.897 } \\
\hline
\end{tabular}

Natural water bodies (NWB), farm on sand (FS), sand plain (SP), forest (F), woodland (WL), burnt area (BA), User's accuracy (UA), and Producer's accuracy (PA) 


\section{Results and discussion}

Figure 2 shows the distributions of GPS location (training reference points) collected during detailed field survey. The analysis of digital elevation model (DEM) reveals that the terrain of West Kordofan sloping from northeast to south (Fig. 3). Maximum elevation occurs at eastern part of the study area approaching $986 \mathrm{~m}$, while the minimum level of land ranges between 364 and $450 \mathrm{~m}$.

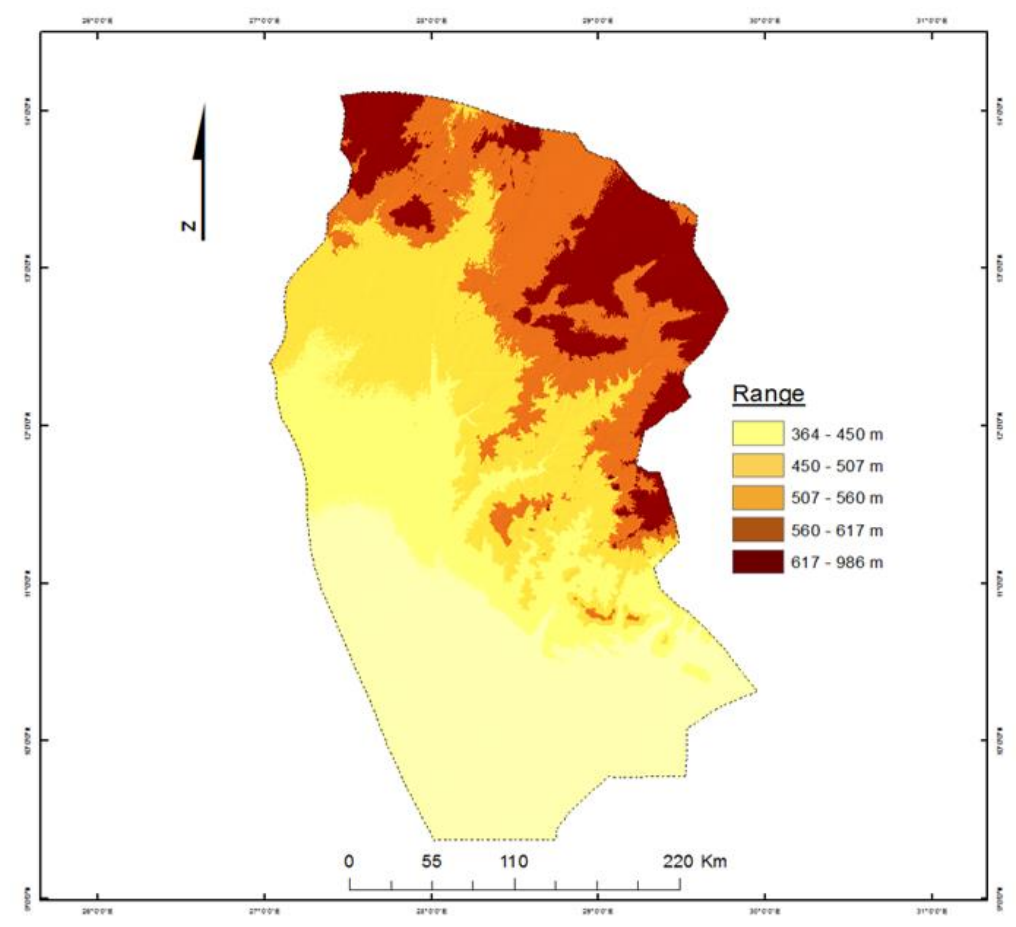

Figure 3. West Kordofan topographic map produced from the SRTM DEM

Confusion matrices showed that the overall accuracies of land cover maps for the year 2000 and 2015, which categorized six land cover classes (natural water bodies, farm on sand, sand plain, forest, woodland and burnt area) were higher or equal to $80.4 \%$ and $91.9 \%$. The Kappa coefficient values were 0.756 and 0.897 , respectively. Most user's and produce's of individual land cover categories were also generally high, ranging from $66.6 \%$ to $95.4 \%$ (Table 2). Single date land cover map was created for each year to show the spatial distribution of six land cover categories in West Kordofan (Fig. 4).

From 2000 to 2015, sand plain, burnt area and forest increased by approximately $7733.23 \mathrm{~km}^{2}$ (43.93\% of the total changed area), $810.27 \mathrm{~km}^{2}(4.6 \%)$ and $258.99 \mathrm{~km}^{2}$ $(1.47 \%)$, respectively. Farm on sand decreased by $6625.73 \mathrm{~km}^{2}(37.64 \%)$, woodland decreased by $2001.8 \mathrm{~km}^{2}(11.37 \%)$ and natural water bodies by $175.78 \mathrm{~km}^{2}(0.99 \%)$. The largest relative change for the period 2000-2015 was observed in the area covered by sand, which increased by $515.55 \mathrm{~km}^{2}$ annually. Sand expanded consistently during the study period. This patterns of sand throughout the study area will be especially important for sand encouragement studies and land degradation as can be seen in Figure 5. The change in sand plain area was followed by the increase in burnt area, $54.02 \mathrm{~km}^{2}$, and in forest, $17.27 \mathrm{~km}^{2}$. Burnt area describes the areas that exposed to 
frequent occurrence of wildfires especially during the end of dry season. The increase in burnt areas are largely due to farm preparations, woody tree clearing, livestock grazing and might be because of ongoing conflict in the region. These making human and the ecosystem more susceptible to sever damage and risks associated with wildfires in West Kordofan. However, the increase in forest resulted mainly from planted and expansion of Acacia Senegal tree (known as gum-gardens). This finding are consistent with previous environmental monitoring and assessment conducted in the Gum belt in Kordofan region to identify the distribution of Acacia Senegal tree (Khiry and Csaplovics, 2007).
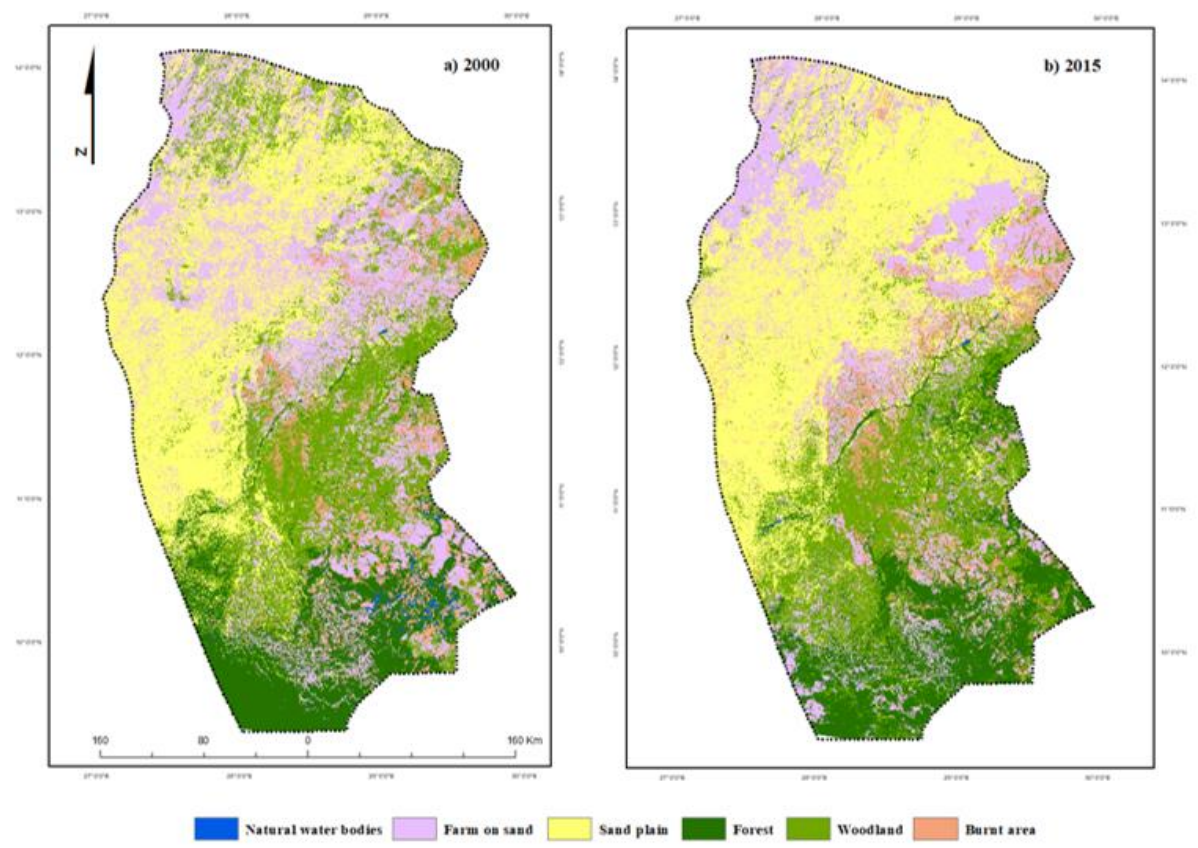

Figure 4. Final land cover maps of West Kordofan for a) 2000 and b) 2015

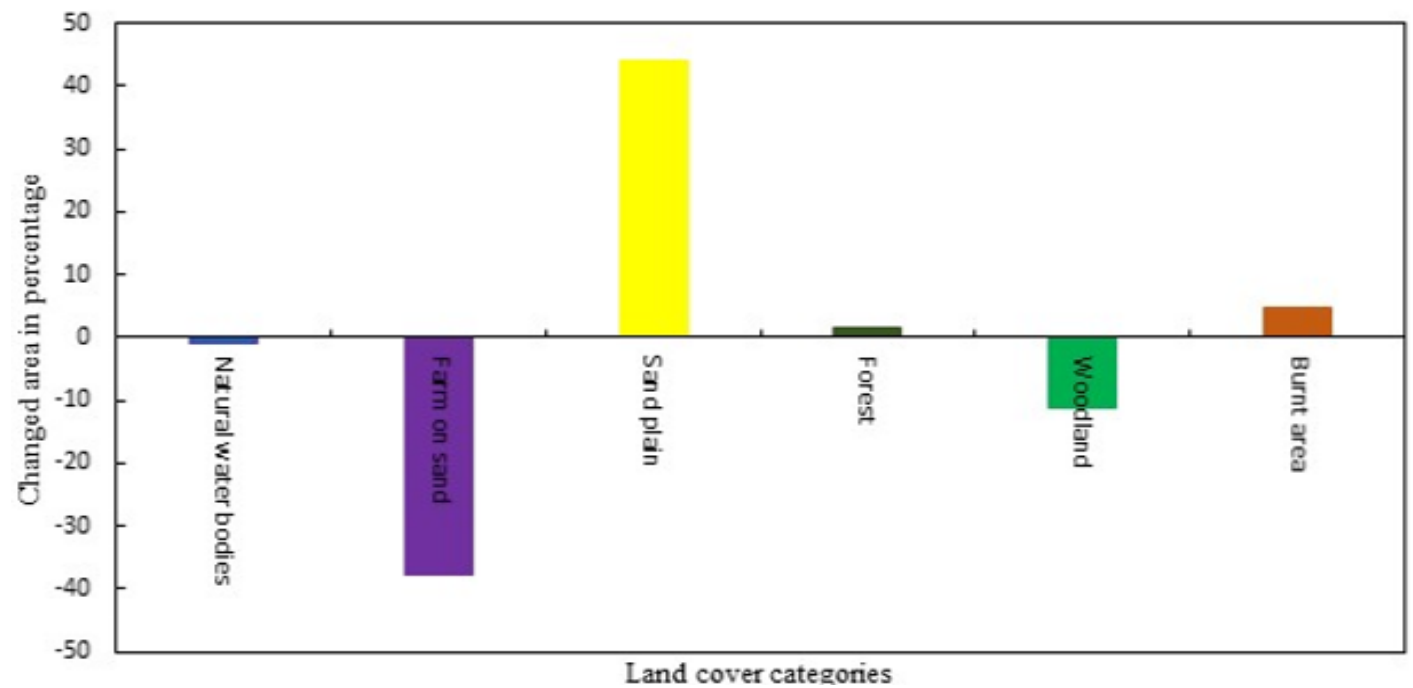

Figure 5. Percentage of areas changed for the six major land cover categories in West Kordofan 
Although the extent of natural water bodies may have changed from year to year due to annual variability in rainfall and temperature, the change (decrease) observed in this category is likely to be partially explained by classification errors.

Spatial coverage under each land cover category for the year 2000 and 2015 were depicted in Table 3. A general look at the final land cover maps shows that the total surface area of West Kordofan is almost $113788.11 \mathrm{~km}^{2}$. The changes in land cover that occurred in West Kordofan between 2000 and 2015 were not spatially homogenous. The two land cover maps produced in the study area revealed that land cover changes varied among the different land cover categories. In general, the central desertified and the northern and northeast were most changed. Sand encouragement primarily occurred in the north and west of the study area, in areas of En Nahud and Ghubaysh in the north and west, respectively.

Forest growth mainly occurred in the south part of West Kordofan, southeast and around the margin of natural water bodies. However, vegetation cover density at the north part of the study area is rather low compared with the south part. In fact, in semiarid areas, vegetation cover is often limited in diversity and complexity. Species like Acacia Senegal (locally known Hashab), is indigenous tree that comprises pure stands distributed over a vast area mixed with farm on sand, which play an important role in economic activities and sand encroachment stability.

The low density of vegetation cover in the north part are perhaps the most important factors in the context of conserving natural resources in West Kordofan. With the human activities, pressure on vegetation cover is increasing with growing demand for fuel wood, charcoal, agriculture expansion (both large and small scale farming) and grazing land covers. These might over time lead to severe deterioration or multidimensional environmental changes as already being reported by (Yagoub et al., 2017).

Table 3. Area and amount of change in different land cover types in West Kordofan during 2000 to 2015

\begin{tabular}{c|c|c|c|c|c|c|c}
\hline \multirow{2}{*}{$\begin{array}{c}\text { Land cover } \\
\text { categories }\end{array}$} & \multicolumn{4}{|c|}{ Spatial area coverage } & \multicolumn{2}{c|}{ Changed area } & $\begin{array}{c}\text { Annual rate } \\
\text { of change }\end{array}$ \\
\cline { 2 - 8 } & \multicolumn{2}{|c|}{$\mathbf{2 0 0 0}$} & \multicolumn{2}{c|}{$\mathbf{2 0 1 5}$} & $\mathbf{2 0 0 0 - 2 0 1 5}$ & $\mathbf{2 0 0 0 - 2 0 1 5}$ \\
\cline { 2 - 8 } & Area $\left(\mathbf{k m}^{\mathbf{2}}\right)$ & $\mathbf{\%}$ & Area $\left(\mathbf{k m}^{\mathbf{2}}\right)$ & $\mathbf{\%}$ & Area $\left(\mathbf{k m}^{\mathbf{2}}\right)$ & $\mathbf{\%}$ & $\mathbf{( \mathbf { k m } ^ { 2 } / \mathbf { y r } )}$ \\
\hline NWB & 653.06 & 0.57 & 477.27 & 0.42 & -175.78 & -0.99 & -11.72 \\
FS & 32148.88 & 28.25 & 25523.16 & 22.43 & -6625.73 & -37.64 & -441.71 \\
SP & 33368.18 & 29.32 & 41101.47 & 36.12 & 7733.28 & 43.93 & 515.55 \\
F & 15629.98 & 13.74 & 15888.97 & 13.96 & 258.99 & 1.47 & 17.27 \\
WL & 25549.07 & 22.45 & 23548.03 & 20.69 & -2001.03 & -11.37 & -133.40 \\
BA & 6438.94 & 5.66 & 7249.22 & 6.37 & 810.27 & 4.60 & 54.02 \\
\hline Total & 113788.12 & 100 & 113788.11 & 100 & 17605.10 & & \\
\hline
\end{tabular}

Farm on sand class was typically used to describe farming practices on sandy soil that rely on rainfall. It was significantly decreased between 2000 and 2015 by almost $441.71 \mathrm{~km}^{2}$ per year from the total changed area. West Kordofan is currently undergoing economic transition processes that affect the use of land directly and indirectly. Change in farms areas is linked directly to socioeconomic development due to the effect of economic growth, oil exploration and mining (Binuomote and Odeniyi, 
2013). Economic growth also influences positively the spatial structure of land cover and land use patterns by improving income opportunities form non-agricultural sectors. Oil exploration in West Kordofan has also been a major factor driving urban development processes, particularly in the south part of the study area. Consequently, some farms land has been transformed rapidly into mining infrastructure in the past two decades. Therefore, it is reasonable to conclude that the changes in different land cover categories are corresponded to economic development and of course desert encouragement towards the south direction of the study area. In this present study important changes in land cover were identified in West Kordofan between 2000 and 2015. These results raise the need for further studies to determine association of the changes and other potential drivers of land cover change with the observed increase in sand plain.

\section{Conclusions}

This study presents an initial attempt to filled current gaps in land cover datasets in West Kordofan of Sudan, and suggest high priority for ecologically sensitive environment (arid and semi-arid areas) do not currently have sufficient scientific information. The results demonstrate that combination of remotely sensed data and geographic information system (GIS) can provide an accurate, economical means to classify and map land cover in a large-scale area and statistics. The results of land cover change analysis conducted in this study concur with large-scale impact of expanding sand plain and burnt area coverage. These findings provide evidence that may help facilitate future land cover and land use planning, management and decision-making in West Kordofan region. In addition, this assessment of land cover changes may also help to explain and respond effectively to emerging environmental risks in West Kordofan region.

Acknowledgements. This work was supported by the special Project for Scientific Research of Forestry Commonwealth Industry of National Forestry Bureau (Grant No. 201404401), and National Key Research and Development Program of China (Project grant No. 2017YFD0600902). The authors would like gratefully acknowledge the United State Geological Survey (USGS) for providing free access to Landsat ETM+ images. We also would like to thank our reviewers for insightful reviews and comments on the manuscript.

\section{REFERENCES}

[1] Akinyemi, F. O., Mashame, G. (2018): Analysis of land change in the dryland agricultural landscapes of eastern Botswana. - Land Use Policy 76: 798-811.

[2] Ayoub, A. (1999): Land degradation, rainfall variability and food production in the Sahelian zone of the Sudan. - Land Degradation \& Development 10(5): 489-500.

[3] Ayoub, A. T. (1998): Extent, severity and causative factors of land degradation in the Sudan. - Journal of Arid Environments 38(3): 397-409.

[4] Badjana, H. M. et al. (2017): Mapping and estimating land change between 2001 and 2013 in a heterogeneous landscape in West Africa: Loss of forestlands and capacity building opportunities. - International Journal of Applied Earth Observation and Geoinformation 63: 15-23.

[5] Baker, C. et al. (2006): Mapping wetlands and riparian areas using Landsat ETM+ imagery and decision-tree-based models. - Wetlands 26(2): 465. 
[6] Binuomote, S., Odeniyi, K. (2013): Effect of crude oil price on agricultural productivity in Nigeria (1981-2010). - International Journal of Applied Agriculture and Apiculture Research 9: 131-139.

[7] Brown, G., Sanders, S., Reed, P. (2018): Using public participatory mapping to inform general land use planning and zoning. - Landscape and Urban Planning 177: 64-74.

[8] Chander, G., Markham, B. L., Helder, D. L. (2009): Summary of current radiometric calibration coefficients for Landsat MSS, TM, ETM+, and EO-1 ALI sensors. - Remote Sensing of Environment 113(5): 893-903.

[9] Chamaille-Jammes, S., Fritz, H., Murindagomo, F. (2006): Spatial patterns of the NDVIrainfall relationship at the seasonal and interannual time scales in an Africa savanna. International Journal of Remote Sensing 27(23): 5185-5200.

[10] Costa, H., Foody, G. M., Boyd, D. S. (2018): Supervised methods of image segmentation accuracy assessment in land cover mapping. - Remote Sensing of Environment 205: 338351.

[11] Dawelbait, M., Morari, F. (2012): Monitoring desertification in a Savannah region in Sudan using Landsat images and spectral mixture analysis. - Journal of Arid Environments 80: 45-55.

[12] Dimobe, K. et al. (2015): Identification of driving factors of land degradation and deforestation in the Wildlife Reserve of Bontioli (Burkina Faso, West Africa). - Global Ecology and Conservation 4: 559-571.

[13] Ehrlich, D., Lambin, E. F., Malingreau, J.-P. (1997): Biomass burning and broad-scale land-cover changes in Western Africa. - Remote Sensing of Environment 61(2): 201-209.

[14] Elagib, N. A. (2015): Drought risk during the early growing season in Sahelian Sudan. Natural Hazards 79(3): 1549-1566.

[15] Elagib, N. A., Elhag, M. M. (2011): Major climate indicators of ongoing drought in Sudan. - Journal of Hydrology 409(3-4): 612-625.

[16] Foody, G. (2001): Monitoring the magnitude of land-cover change around the southern limits of the Sahara. - Photogrammetric Engineering and Remote Sensing 67(7): 841847.

[17] Foody, G. M. (2010): Assessing the accuracy of land cover change with imperfect ground reference data. - Remote Sensing of Environment 114(10): 2271-2285.

[18] Friedl, M. A. et al. (2002): Global land cover mapping from MODIS: algorithms and early results. - Remote Sensing of Environment 83(1-2): 287-302.

[19] Hansen, M. C., Loveland, T. R. (2012): A review of large area monitoring of land cover change using Landsat data. - Remote Sensing of Environment 122: 66-74.

[20] Higginbottom, T. P. et al. (2018): Mapping fractional woody cover in semi-arid savannahs using multi-seasonal composites from Landsat data. - ISPRS Journal of Photogrammetry and Remote Sensing 139: 88-102.

[21] Huang, H. et al. (2017): Mapping major land cover dynamics in Beijing using all Landsat images in Google Earth Engine. - Remote Sensing of Environment 202: 166-176.

[22] Kashaigili, J. J., Mbilinyi, B. P., Mccartney, M., Mwanuzi, F. L. (2006): Dynamics of Usangu plains wetlands: Use of remote sensing and GIS as management decision tools. Physics and Chemistry of the Earth, Parts A/B/C 31(15-16): 967-975.

[23] Khiry, M. A., Csaplovics, E. (2007): Appropriate methods for monitoring and mapping land cover changes in semi-arid areas in North Kordofan (Sudan) by using satellite imagery and spectral mixture analysis. - Analysis of Multi-temporal Remote Sensing Images, 2007. MultiTemp 2007. International Workshop, IEEE, pp. 1-4.

[24] Lambin, E. F., Ehrlich, D. (1997): Land-cover changes in sub-Saharan Africa (19821991): Application of a change index based on remotely sensed surface temperature and vegetation indices at a continental scale. - Remote Sensing of Environment 61(2): 181200. 
[25] Lambin, E. F., Geist, H. J., Lepers, E. (2003): Dynamics of land-use and land-cover change in tropical regions. - Annual Review of Environment and Resources 28(1): 205241.

[26] Leiterer, R. et al. (2018): Vegetation monitoring in refugee-hosting areas in South Sudan. - Applied Geography 93: 1-15.

[27] Liu, K. et al. (2018): Large-scale mapping of gully-affected areas: An approach integrating Google Earth images and terrain skeleton information. - Geomorphology 314: 13-26.

[28] Lu, D. et al. (2004): Change detection techniques. - International Journal of Remote Sensing 25(12): 2365-2401.

[29] Lu, D., Weng, Q. (2007): A survey of image classification methods and techniques for improving classification performance. - International Journal of Remote Sensing 28(5): 823-870.

[30] Madonsela, S. et al. (2018): Estimating tree species diversity in the savannah using NDVI and woody canopy cover. - International Journal of Applied Earth Observation and Geoinformation 66: 106-115.

[31] Padonou, E. A. et al. (2017): Mapping changes in land use/land cover and prediction of future extension of bowé in Benin, West Africa. - Land Use Policy 69: 85-92.

[32] Petropoulos, G. P., Kontoes, C. C., Keramitsoglou, I. (2012): Land cover mapping with emphasis to burnt area delineation using co-orbital ALI and Landsat TM imagery. International Journal of Applied Earth Observation and Geoinformation 18: 344-355.

[33] Rogan, J. et al. (2003): Land-cover change monitoring with classification trees using Landsat TM and ancillary data. - Photogrammetric Engineering \& Remote Sensing 69(7): 793-804.

[34] Salih, A. A., Ganawa, E.-T., Elmahl, A. A. (2017): Spectral mixture analysis (SMA) and change vector analysis (CVA) methods for monitoring and mapping land degradation/desertification in arid and semiarid areas (Sudan), using Landsat imagery. The Egyptian Journal of Remote Sensing and Space Science 20: S21-S29.

[35] Schulz, J. J. et al. (2010): Monitoring land cover change of the dryland forest landscape of Central Chile (1975-2008). - Applied Geography 30(3): 436-447.

[36] Sinha, P., Kumar, L., Reid, N. (2016): Rank-based methods for selection of landscape metrics for land cover pattern change detection. - Remote Sensing 8(2): 107.

[37] Yagoub, Y. E. et al. (2017): Investigation of Vegetation Cover Change in Sudan by Using Modis Data. - Journal of Geographic Information System 9(03): 279.

[38] Yousefi, S. et al. (2015): Accuracy assessment of land cover/land use classifiers in dry and humid areas of Iran. - Environmental Monitoring and Assessment 187(10): 641. 